\title{
Seasonal Change of Germination of Poa crassinervis Honda
}

\author{
Osamu Watanabe*, Takashi Enomoto**, Katsuhisa Nishi**, Toshiko Matano*** \\ and Tohru Tominaga***
}

\begin{abstract}
Seasonal change in germination of $P$. crassinervis was compared to that of $P$. annua collected from the same habitat. Germination tests were made at 10, 15, 20, 25 and $30^{\circ} \mathrm{C}$. To analyze the three phases of the germination process: the final cumulative germination percentage, the weighted mean germination ratio and the onset of germination, the cumulative seed germination curve was fitted to Richards' function model. $P$. crassinervis seeds germinated from late summer to early winter, while $P$. annua germinated throughout the year at $10^{\circ} \mathrm{C}$. In both species, high cumulative germination percentage was found from August to December except for $P$. crassinervis seeds at $30^{\circ} \mathrm{C}$. Cumulative germination curves of both species were very well fitted to Richards' function model. The time to reach maximum germination percentage in $P$. crassinervis was always shorter than that of $P$. annua when seeds were incubated at 10, 15, 20 and $25^{\circ} \mathrm{C}$. An apparent seasonal dormant and non-dormant cycle and immediate germination were found in $P$. crassinervis. The germination characteristics of $P$. crassinervis

* The United Graduate School of Agricutural Science, Gifu University (Shinshu University), 8304 Minamiminowa, Kamiina, Nagano 399-45, Japan.

** Research Institute for Bioresources, Okayama University, Kurashiki 710, Japan.

*** Faculty of Agriculture, Shinshu University 8304 Minamiminowa, Kamiina, Nagano 399-45, Japan.
\end{abstract}

(Received June 20, 1996) seemed to be disadvantageous for seedling establishment in a severely disturbed habitat.

Key words : Poa crassinervis, P. annua, Richards' function model, seasonal change of germination

\section{Introduction}

Poa crassinervis Honda is an annual winter weed distributed in drained paddy fields, upland fields, roadsides and gardens in western Japan. P. annua L., a closely related species of $P$. crassinervis, is a cosmopolitan weed and very adaptable. Many reports are found on the ecological and phenological characters of $P$. annua ${ }^{12,16)}$, but no studies have been attempted on $P$. crassinervis.

The germination and dormancy mechanisms of seeds are of great adaptive importance in ensuring that seedling emergence occurs at the most advantageous time and place ${ }^{8)}$. Seed germination is one of the most critical developmental phases in the life cycle of a plant ${ }^{10)}$. Studies on the life cycles of many annual winter species such as Viola arvensis Murr. ${ }^{7}$, Capsella bursa-pastoris L.5), Veronica federifolia L. ${ }^{14)}$, Lamium purpureum L. ${ }^{3)}$ and Lesquerella stonensis Rollins ${ }^{6)}$ show that the seeds do not germinate during summer but begin germination in autumn. Weed seeds in soil go through annual dormant and non-dormant cycles and these responses are important life cycle adaptations to the habitat ${ }^{4)}$. Therefore, determining the seasonal 
change of germination is important to know the life history characteristics of the weed.

The functional approach to plant growth analysis has been applied to cumulative germination data ${ }^{15}$. The Richards' function model which is one of the most expanded logistic functions is useful for fitting the cumulative seed germination curve $e^{9,11,13)}$. Parameters of the final percentage of cumulative germination, the weighted mean germination ratio and the onset of germination may be pertinent to the analysis of ecological characteristics including the seedling establishment in the habitat. We use this model to analyze the germination characteristics of P. crassinervis.

The purpose of this study was to clarify the seasonal change of seed germination of $P$. crassinervis. Germination of this species was compared to that of $P$. annua which was collected from the same habitat.

\section{Materials and Methods}

\section{Seed collection and burial in soil}

Mature seeds of $P$. crassinervis and $P$. annua were collected from a winter cabbage (Brassica oleracea L. var. capitata L.) field at Takanabe, Miyazaki Prefecture $\left(32^{\circ} 08^{\prime} \mathrm{N}\right.$, $131^{\circ} 31^{\prime} \mathrm{E}$ ) on March 17, 1994. Both weeds were dominant in this field. Two variants of $P$. annua, an annual and a perennial, were reported $^{16)}$, the $P$. annua we collected was the annual. After collection, the seeds of both species were dried in the laboratory. On May 6, 1994, about 10,000 seeds of each species divided into 12 lots were packed in 0.5 $\mathrm{mm}$ mesh cloths. Packed seeds were buried at a depth of $5-10 \mathrm{~cm}$ in the upland field of the Research Institute for Bioresources, Okayama University in Kurashiki. All buried seeds remained under that natural condition until the germination test was started.

\section{Seasonal change of germination}

Before burial treatment, seed germination of the two species was tested on May 1, 1994. The germination test was conducted under five different temperatures, 10, 15, 20, 25 and $30^{\circ} \mathrm{C}(12 \mathrm{~h} \mathrm{dark} / 12 \mathrm{~h}$ light, 6,200 lux) for 20 days. Seeds were placed on moist filter paper in $9 \mathrm{~cm}$ glass petri dishes, germination was recorded daily and germinated seeds were removed. Radicle emergence was the criterion for germination ${ }^{1)}$. The test was conducted with three replications of fifty seeds for each species. The seeds buried in soil were dug up at about one month intervals from June, 1994 to May, 1995 and another germination test was made as above.

\section{Analysis of cumulative germination curve}

We used the Richards' function model to analyze the cumulative seed germination curve. The Richards' function defines a family of asymptotic curves including special cases of the monomolecular, autocatalytic (logistic) and Gompertz functions and is effective and flexible in fitting the plant growth curve ${ }^{11}$. It has been used by several authors to fit cumulative growth or germination data ${ }^{9,13)}$. Estimated parameters were calculated to use the nonlinear optimum program of Simplex which utilized Fujii's method $^{9)}$. Following Lehle and Putnam ${ }^{11)}$, the forms of the functions were defined as:

$$
\begin{array}{ll}
W=A\{1+b \exp (-k t)\}^{1 / 1-m} & \text { for } m>1 \\
W=A\{1-b \exp (-k t)\}^{1 / 1-m} & \text { for } m<1
\end{array}
$$

where $W$ is cumulative germination percentage at time $t$. The parameters of $b, k$ and $m$ were calculated by Simplex method to use the empirical initial values. The practically used range was as follows : $2<b<10,0.3<$ $k<4$ and $1.0001<m<2.2$. $A$ is the practical data of final cumulative germination percentage. According to Richards' ${ }^{\prime 3)}$, the area under the curve is calculated as $A^{2} k(2 m+$ 
$2)^{-1}$. Hence the mean height is $A^{2} K(2 m+$ $2)^{-1} / A$. An alternative interpretation of this parameter is the weighted mean cumulative germination ratio $(\mathrm{R})$. $\mathrm{R}$ indicates germination percentage per day throughout the whole period of germination and was defined as:

$$
R=A k(2 m+2)^{-1}
$$

According to Fujii et $a l^{9}{ }^{9)}$, the onset of germination ( $\mathrm{Ts}$ ) indicating the time required to germinate one seed when germination percentage is $100 \%$ was defined as :

$$
\begin{array}{cc}
\left.T S=\ln \left[\{1 / n)^{(1-m)}-1\right\} / b\right] /(-k) & \text { for } m>1 \\
T S=\ln \left[\left\{1-(1 / n)^{(1-m)}\right\} / b\right] /(-k) & \text { for } m<1
\end{array}
$$

where $\mathrm{n}$ is the number of seeds used in the germination test.

\section{Results and Discussion}

\section{Seasonal change of germination}

Seasonal change of cumulative seed germination percentage of the two species is shown in Fig. 1. No seeds of either species germinated at any temperature before burial treatment in May, 1994 ; all were in the primary dormant state. In P. crassinervis, $26 \%$ of the seeds germinated at $10^{\circ} \mathrm{C}$ and $5 \%$ at $15^{\circ} \mathrm{C}$ after one month burial but none at the other temperatures. In July after two months burial, more than $95 \%$ of the $P$. crassinervis seeds germinated at 10 and $15^{\circ} \mathrm{C}$ and $71 \%$ at $20^{\circ} \mathrm{C}$. P. crassinervis seeds buried for one or two months germinated at lower temperatures, and the maximum temperature for germination gradually increased with the duration of burial. From August to November, $94-100 \%$ of the P. crassinervis seeds germinated at $10-25^{\circ} \mathrm{C}$, but few of them germinated at $30^{\circ} \mathrm{C}$ in any season. From November to January, their cumulative germination percentage drastically dropped at all temperatures and from January to March, the seeds hardly germinated at any tempera-

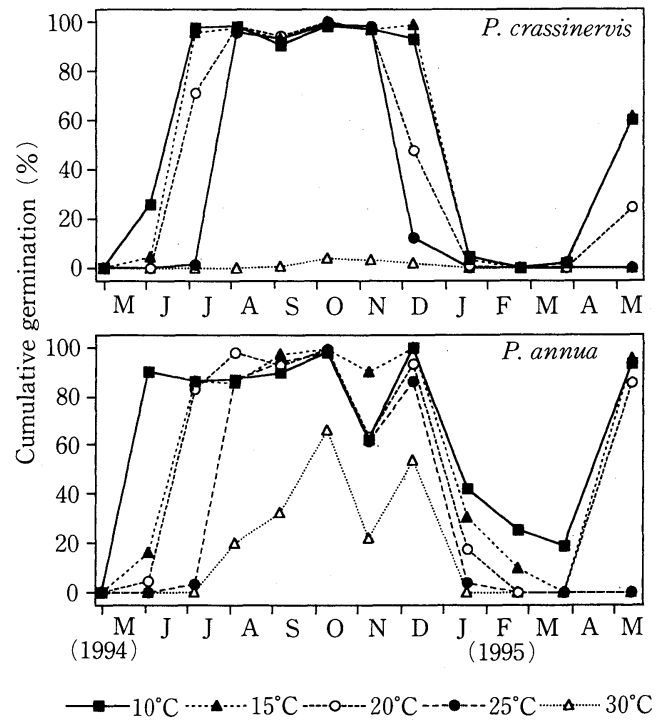

Fig. 1. Seasonal change of cumulative germination percentage in $P$. crassinervis and $P$. annua seeds following 0 to 372 days of burial.

Seeds of both species were buried on May 6, 1994 and dug up at one month intervals. Germination tests were conducted at $10,15,20,25$ and $30^{\circ} \mathrm{C}$ for 20 days.

ture. In May, 1995, about $60 \%$ of the $P$. crassinervis seeds germinated at 10 and $15^{\circ} \mathrm{C}$. Thus, seasonal change of dormant and nondormant cycle was clearly recognized in this species.

In $P$. annua, 90,16 and $5 \%$ of the seeds germinated at 10,15 and $20^{\circ} \mathrm{C}$ after one month burial, respectively. After two months burial, $86 \%$ germinated at 10 and $15^{\circ} \mathrm{C}$, and $83 \%$ at $20^{\circ} \mathrm{C}$. These seeds also germinated at lower temperatures after one or two months burial and germinated well from August to October. At $30^{\circ} \mathrm{C}$ in which temperature the $P$. crassinervis seeds germinated little, 20$66 \%$ of the $P$. annua seeds germinated. In November, cumulative germination percentages at each temperature temporarily decreased although the reason for this is not clear. From January to February, cumulative germination percentage dropped at all 
temperatures. At $10^{\circ} \mathrm{C}, 19-42 \%$ of the $P$. annua seeds germinated from January to March : they hardly germinated at the other temperatures in March. In May, 1995, 86$95 \%$ of the $P$. annua seeds germinated at 10 , 15 and $20^{\circ} \mathrm{C}$; thus these seeds germinated throughout the year at $10^{\circ} \mathrm{C}$.

In June after one month burial, higher cumulative germination percentages were found in $P$. annua than in $P$. crassinervis, indicating that the primary dormancy of it may be deeper than that of $P$. annua. The same result was found in a previous study on the effect of storage temperature and period on the germination of freshly harvested seeds of $P$. crassinervis $^{17)}$.

From August to December, high cumulative seed germination percentages were found at the wide ranging temperatures except for $30^{\circ} \mathrm{C}$ of $P$. crassinervis. The primary dormancy of seeds in both species seemed to be broken in this period, and the maximum and range of temperature for germination increased as shown in Arabidopsis thaliana (L.) Heynh. ${ }^{2)}$ and L. stonensis ${ }^{6}$. Dormant seeds of some annual winter weeds afterripen at high temperature and their primary dormancy is broken ${ }^{1 \sim 3)}$. High summer temperature is required for completion of the life cycle ${ }^{3)}$ and for $P$. crassinervis, $30^{\circ} \mathrm{C}$ was required to break primary seed dorman$\mathrm{cy}^{17)}$.

When the seeds of winter annuals such as Lamium amplexicaule L. ${ }^{3)}, V$. federifolia ${ }^{14)}, C$. bursa-pastoris ${ }^{5)}$ and L. stonensis ${ }^{6)}$ which fully afterripen were exposed to low temperature, these seeds went into a secondary dormant state. From January to April, P. crassiner vis and $P$. annua seeds might be in a secondary dormant state (Fig. 1). In December, final germination percentage of $P$. crassiner vis at 20 and $25^{\circ} \mathrm{C}$ dropped drastically, but that of $P$. annua seeds did not, germinating throughout the year at $10^{\circ} \mathrm{C}$ (Fig. 1). The degree of secondary dormancy seemed to be stronger in $P$. crassinervis than in $P$. annua.

\section{Analysis of cumulative germination curve}

In Fig. 2, cumulative seed germination curves at $10,15,20$ and $25^{\circ} \mathrm{C}$ fitted to Richards' function model are shown from September to December. All curves were simulated for $m>1$ and were very well fitted to this model. The time to reach the maximum germination percentage of $P$. crassinervis seeds was always shorter than that of $P$. annua at any temperature (Fig. 2). The weighted mean germination ratio $(\mathrm{R})$ and the onset of germination (Ts) calculated by Richards' function are shown in Fig. 3 ; both were affected by the test temperature. $P$. crassinervis seeds tested at 20 and $25^{\circ} \mathrm{C}$ initiated germination within five days and the highest weighted mean germination ratios (59$69 \%$ ) were found in October and November. In $P$. annua, the seeds tested at 20 and $25^{\circ} \mathrm{C}$ initiated germination within five days, and those tested at $30^{\circ} \mathrm{C}$ within four days. $\mathrm{R}$ of $P$. annua showed $35-61 \%$ at 20 and $25^{\circ} \mathrm{C}$ from September to December except for November. From September to November, $\mathrm{R}$ of the $P$. crassinervis was higher than that of $P$. annua at $10-25^{\circ} \mathrm{C}$ except for the September test at $25^{\circ} \mathrm{C}$. The optimum temperature for germination of $P$. crassinervis seemed to be 20 and $25^{\circ} \mathrm{C}$ during the autumn.

$P$. crassinervis seeds had a clear seasonal dormant and non-dormant cycle. According to Baskin and Baskin ${ }^{6}$, L. stonensis the narrowly endemic weed native to the Central Basin of Tennessee germinated only in autumn in the field. They referred to this species as an obligate winter annual. When the seeds are exposed to low temperature in winter, they enter secondary dormancy and do not germinate. Other narrowly endemic winter annuals such as Leavenworthia spp. 


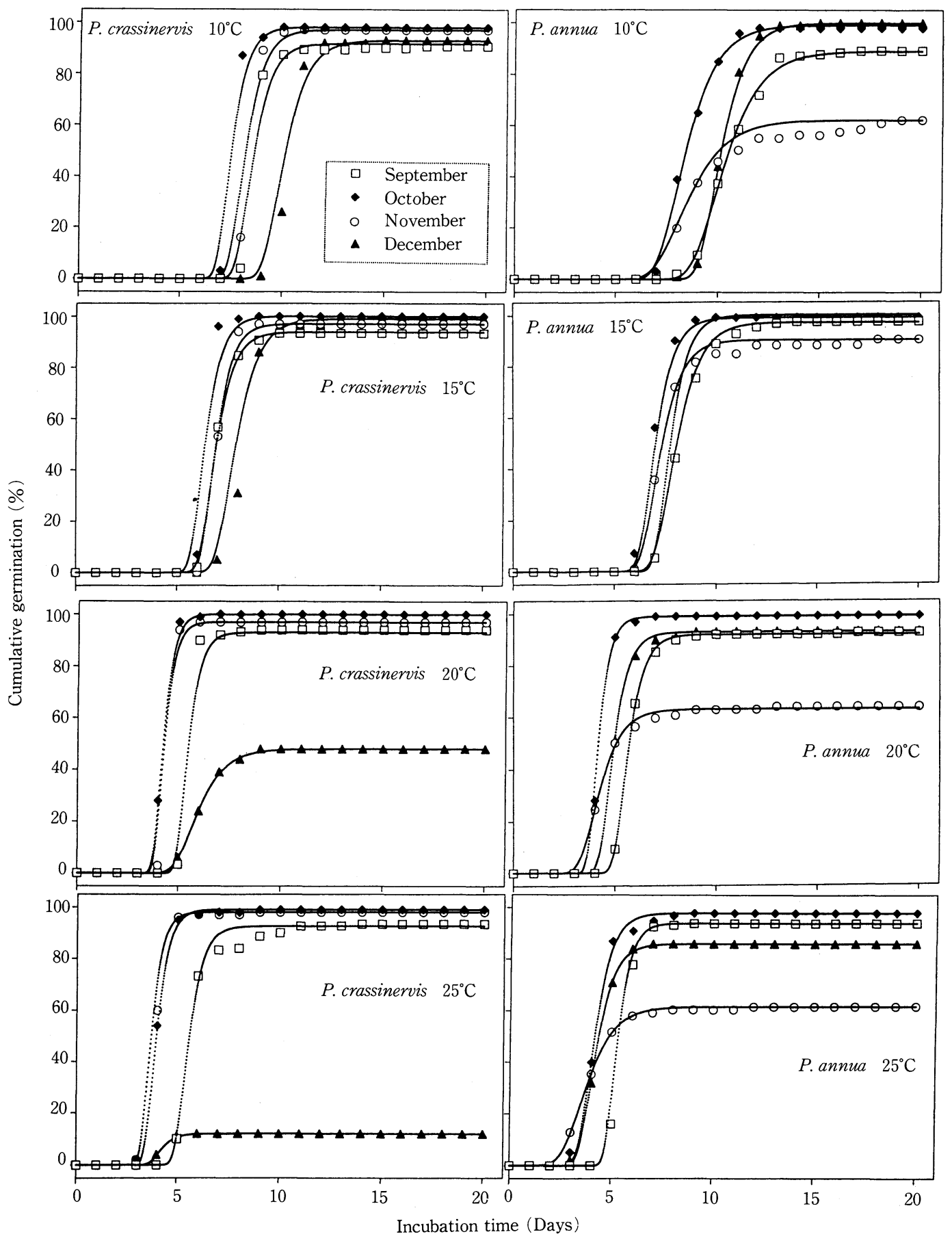

Fig. 2. Comparison of cumulative germination curves of $P$. crassinervis and $P$. annua seeds tested at 10,15 , 20 and $25^{\circ} \mathrm{C}$ from September to December, 1994.

These curves were fitted to the Richards' function model. 


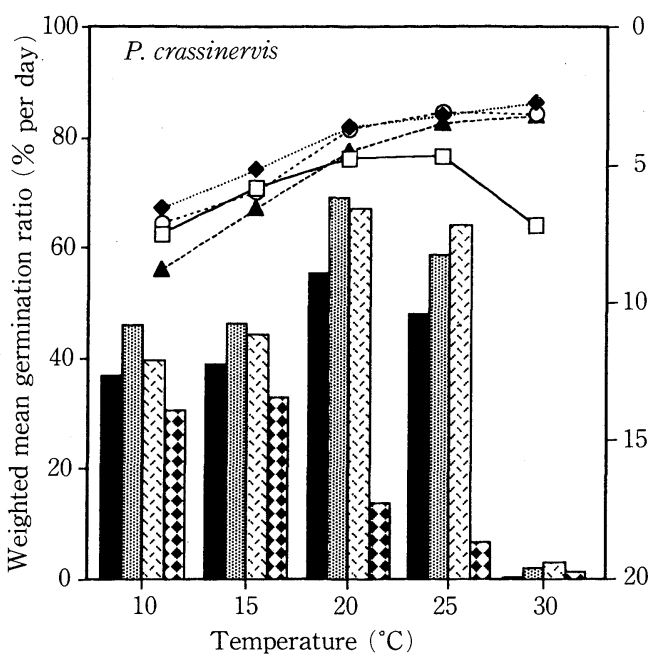

Weighted mean 口国国国

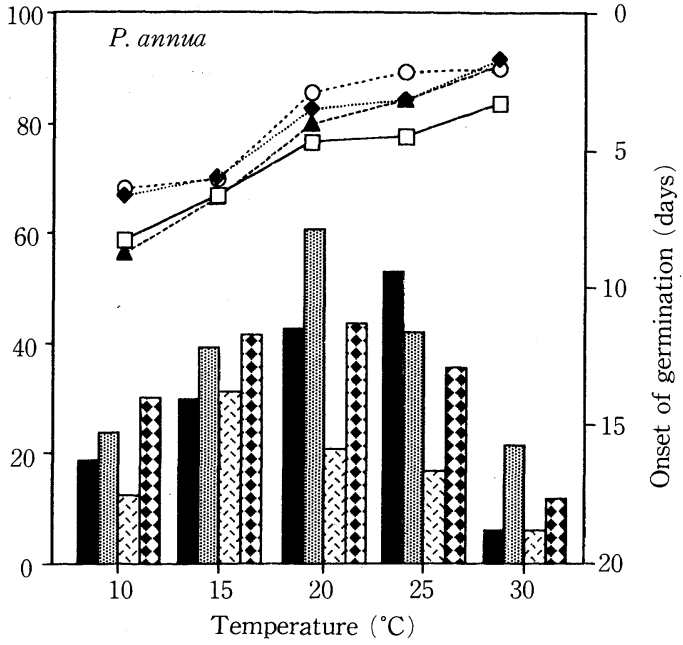

$\begin{array}{lrrrr}\text { Onset of } & \square & & & \\ \text { germination } & \text { Sep. } & \text { Oct. } & \text { Nov. } & \text { Nov. }\end{array}$

Fig. 3. Effect of temperature on the weighted mean germination ratio (R) and the onset of germination (Ts) culculated by Richards' function model resulting from fitting to cumulative germination curves of $P$. crassinervis and $P$. annua.

Curve fitting was conducted from September to December, 1994.

and Phacelia dubia (L.) Trel. var. interior Fern. are also obligate winter annuals $\left.{ }^{6}\right) ;$. crassinervis can be referred to as an obligate winter annual weed based on the results of this study. In contrast, geographically widespread winter annual weeds are of obligate and facultative types; a facultative type does not show secondary dormancy. $P$. annua tested in this study is thus referred to as a facultative winter annual weed.

$P$. crassinervis seeds germinated more quickly and immediately than $P$. annua seeds under an adequate germination temperature. $P$. crassinervis seldom occurs in a severely trampled or disturbed site, and its germination characteristics seem disadvantageous for seedling establishment in a severely disturbed habitats.

Acknowledgement $\mathrm{We}$ are grateful to Dr. Y. Fujii of the National Institute of AgroEnvironmental Sciences for offering the pro- gram of Simplex method for Richards' function model.

\section{References}

1) Baskin, J.M. and C.C. Baskin 1976. High temperature requirement for afterripening in seed of winter annuals. New Phytol. 77, 619-624.

2) Baskin, J.M. and C.C. Baskin 1983. Seasonal change in the germination responses of buried seeds of Arabidopsis thaliana and ecological interpretation. Bot. Gaz. 144, 540-543.

3) Baskin, J.M. and C.C. Baskin 1984. Role of temperature in regulating timing of germination in soil seed reserves of Lamium purpur. eum L. Weed Res. 24, 341-349.

4) Baskin, J.M. and C.C. Baskin 1985. The annual dormancy cycle in buried weed seeds: A Continuum. BioScience 35(8), 492-498.

5) Baskin, J.M. and C.C. Baskin 1989. Germination responses of buried seeds of Capsella bursa-pastoris exposed to seasonal temperature changes. Weed Res. 29, 205-212.

6) Baskin, J.M. and C.C. Baskin 1990. Seed germination biology of the narrowly endemic 
species Lesquerella stonensis (Brassicaceae). Plant Species Biology 5, 205-213.

7) Baskin J.M. and C.C. Baskin 1995. Variation in the annual dormancy cycle in buried seeds of the weedy winter annual Viola arvensis. Weed Res. 35, 353-362.

8) Bewley, J.D. and M. Black 1982. Seeds: Physiology of development and Germination. Plenum Press, New York. pp. 175-177.

9) Fujii, Y, T. Shibuya and T. Yasuda 1990. Methods for screening allelopathic activities by using the logistic function (RICHARDS' function) fitted to lettuce seed germination and growth curves. Weed Res, Japan 35, 353-361. (in Japanese with English summary)

10) Koller, D., M. Sachs and M. Negbi 1964. Germination-regulating mechanisms in some desert seeds. VIII. Artemisia monosperma. Plant \& Cell Physiol. 5, 85-100.

11) Lehle, F.R. and A.R. Putnam 1982. Quantification of allelopathic potential of sorghum residues by novel indexing of Richards' function fitted to cumulative cress seed germination curves. Plant Physiol. 69, 1212-1216.
12) Lush, W.M. 1989. Adaptation and differentiation of golf course population of annual bluegrass (Poa annua). Weed Science 37, 54-59.

13) Richards F.J. 1959. A flexible growth function for empirical use. Journ. of Experimental Botany. 29, 290-300.

14) Roberts, H.A. and J.E. Neilson 1982. Role of temperature in the seasonal dormancy of seeds of Veronica hederifolia L. New Phytol. 90, 745-749.

15) Thompson, C.R., C.T. Donald and S. Bahman 1994. Germination characteristics of Sulfonylurea-resistant and -susceptible Kochia (Kochia scoparia). Weed Science 42, 50-56.

16) Warwick, S.I. 1979. The biology of Canadian weeds. 37 Poa annua L. Can. J. Plant Sci. 59, 1053-1066.

17) Watanabe, O, T. Enomoto, K. Nishi, T. Matano and T. Tominaga 1996. Effect of storage temperature and period on seed germination of Poa crassinervis Honda. Weed Res., Japan 41(2), 116-119.

\section{ツクシスズメノカタビラの発芽の季節変化}

\author{
渡辺 修*・榎本 敬**. 西 克久**・ \\ 俣野敏子***・冨永 達***
}

\section{摘要}

ツクシスズメノカタビラは西日本に分布が限ら れ, 水田, 畑, 路傍や街路樹の植え込みなどに生育 している。一方, 本種に近縁なスズメノカタビラは 世界的に分布する。本研究ではツクシスズメノカタ ビラの発芽の季節変化をスズメノカタビラのそれ と比較した。宮崎県の畑地から採集した両種の種子 を 5 月 6 日に埋土し, 翌年の 5 月まで約 1 力月おき に掘り出して $10,15,20,25$ および $30^{\circ} \mathrm{C}$ (12 時間 明暗）で発芽試験を行った。また，累積発芽曲線に

\footnotetext{
$*$ 岐阜大学大学院連合農学研究科

** 岡山大学資源生物科学研究所

*** 信州大学農学部
}

最も拡張されたロジスティック関数の一つである Richards 関数をあてはめ, 最終発芽率, 平均発芽速 度（1 日当たりの発芽率）および発芽開始時間のパ ラメーターで発芽試験の結果を解析した。

埋土処理を行わなかった両種の種子はまったく 発芽せず，一次休眠の状態にあった。ツクシスズメ

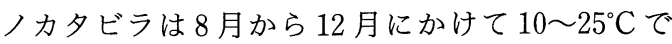
高い発芽率を示したが, $30^{\circ} \mathrm{C}$ ではどの季節でもほと んど発芽しなかった。また，12月から 1 月にかけて ツクシスズメノカタビラの発芽率はすべての温度 で急激に低下し，2月から 3 月にかけてほとんど発 芽しなかった（Fig. 1)。これは種子が二次休眠に 入ったためであると考えられる。スズメノカタビラ も 8 月から 12 月にかけて $10 \sim 25^{\circ} \mathrm{C}$ で高い発芽率 を示し, $30^{\circ} \mathrm{C}$ でも $50 \%$ 前後発芽した。冬季の発芽率 の低下はツクシスズメノカタビラよりも鈍く, $10^{\circ} \mathrm{C}$ では一年を通して発芽した。

Richards 関数から計算した平均発芽速度 (R) は 両種とも秋から冬にかけて $20 \sim 25^{\circ} \mathrm{C}$ で最も高かっ 
た。ツクシスズメノカタビラの平均発芽速度はスズ メノカタビラよりも常に高かった。これはツクシス ズメノカタビラの種子が秋に一斉に発芽すること を示している。この性質は擋乱程度の高い生育地で は実生の定着に関してスズメノカタビラより不利
であるように思われる。

キーワード : ツクシスズメノカタビラ, スズメノカ タビラ, Richards 関数, 発芽の季節変化 